\title{
Peningkatan Kemampuan Berkemih Melalui Senam Kegel Bagi Lansia di Loka Rehabilitasi Sosial Lanjut Usia Minaula Kendari
}

\author{
Rahmawati $^{1},{ }^{*}$ La Ode Alifariki ${ }^{2}$, Haryati $^{3}$, La Rangki ${ }^{4}$, Sukurni $^{5}$ \\ 1,2, Universitas Halu Oleo, Indonesia \\ ners_riki@yahoo.co.id
}

\begin{abstract}
ABSTRAK
Jenis-jenis perubahan terjadi pada lansia, salah satunya menurunkan kemampuan buang air kecil, yaitu penurunan tonus otot vagina dan otot saluran kemih (uretra) yang disebabkan oleh hormon estrogen yang menurun, menyebabkan inkontinensia urin yang ototnya menjadi lemah, meningkatkan frekuensi kemih dan tidak mampu untuk mengontrol urin. Komplikasi yang ditimbulkan seperti infeksi saluran kemih, infeksi kulit pubis, gangguan tidur, dekubitus, dan gejala ruam. Selain itu, masalah psikososial seperti dijauhi oleh orang lain karena berbau urin, inferior, tidak percaya diri, mudah marah sering terjadi dan ini mengakibatkan depresi dan isolasi sosial. Satu terapi untuk mengurangi inkontinensia urin dengan melakukan latihan kegel. Ada 30 lansia yang mengalami inkontinensia urin di Pusat Rehabilitasi Sosial Minaula Kendari. Solusi yang digunakan untuk mengatasi masalah ini adalah dengan konseling tentang inkontinensia urin dan latihan Kegel secara teratur. Hasil dari kegiatan tersebut menunjukkan bahwa lansia yang melakukan senam kegel secara teratur, memiliki efek positif di mana lansia mengalami peningkatan kemampuan buang air kecil dengan benar, dan penurunan terjadinya keluarnya air seni spontan tanpa disadari (ngompol).
\end{abstract}

Kata Kunci: Kegel Exercise, Lanjut Usia, Inkontinensia Urin

Received: October, 25, 2019

Revised: December 14, 2019

Accepted: February 11, 2020

This is an open-acces article distributed under the terms of the Creative Commons Attribution-ShareAlike 4.0 International License.

\section{PENDAHULUAN}

Secara fisiologis proses menua merupakan penurunan secara bertahap dan teratur dari organ atau sistem organ serta penurunan kendali homeostasis (Wandera S, Betty, James. 2015). Berbagai macam perubahan terjadi pada lanjut usia, salah satunya pada system perkemihan yaitu penurunan tonus otot vagina dan otot pintu saluran kemih (uretra) yang disebabkan oleh penurunan hormone esterogen, sehingga menyebabkan terjadinya Inkontinensia Urine, otot-otot menjadi lemah, sehingga menyebabkan frekuensi BAK meningkat dan tidak dapat dikontrol (Anggelita, 2012)

Menurut The National Kidney and Urologyc Disease Advisory Board di Amerika Serikat, jumlah penderita inkontinensia mencapai 13 juta dengan 85 persen diantaranya perempuan (Dunn MJ, 1990). Jumlah ini sebenarnya masih sangat sedikit dari kondisi sebenarnya, sebab masih banyak kasus yang tidak dilaporkan (Maas et al, 2011).

Di Indonesia jumlah penderita Inkontinensia urin sangat signifikan. Pada tahun 2006 diperkirakan sekitar 5,8\% dari jumlah penduduk mengalami Inkontinensia urin (Depkes, 2012). Lansia yang mengalami Inkontinensia urine di Loka Rehabilitasi Sosial Minaula Kendari sejumlah 
30 orang, tetapi belum mendapatkan penanganan atau pemberian latihan-latihan yang efektif (LRSU Minaula Kendari, 2018).

Tingginya angka kejadian inkotinensia urin menyebabkan perlunya penanganan yang sesuai, karena jika tidak segera ditangani, inkontinensia dapat menyebabkan berbagai komplikasi seperti infeksi saluran kemih, infeksi kulit daerah kemaluan, gangguan tidur, dekubitus, dan gejala ruam (Purnomo, 2012). Selain itu, masalah psikososial seperti dijauhi orang lain karena berbau pesing, minder, tidak percaya diri, mudah marah juga sering terjadi dan hal ini berakibat pada depresi dan isolasi sosial (Stanley, M., \& Beare, P. G. 2006).

Salah satu terapi yang efektif untuk menurunkan inkontinensia urin adalah dengan melakukan senam kegel bagi lansia. Latihan senam kegel dapat menurunkan frekuensi berkemih. (Darmojo, R. dan Martono, H, 2006). Kegel exercise adalah latihan kontraksi otot dasar secara aktif yang bertujuan untuk meningkatkan otot dasar panggul (Rahardjo E. H., 2012). Latihan kegel sangat bermanfaat untuk menguatkan otot rangka pada dasar panggul, sehingga memperkuat fungsi sfingter reksternal pada kandung kemih (Pudjiastuti. 2003).

Tujuan dari kegiatan penyuluhan kesehatan tentang Inkontinensia urine adalah untuk meningkatkan pengetahuan lansia mengenai Inkontinensia urine, menanamkan kesadaran untuk mencegah terjadinya inkontinensia urine serhingga dapat meningkatkan status kesehatan lansia.

\section{METODE}

Kegiatan pengabdian pada masyarakat ini akan dilakukan melalui serangkaian kegiatan sebagai solusi yang ditawarkan untuk mengatasi permasalahan yang ada di LRSU Minaula Kendari sebagai instansi pada dibawah Kementrian Sosial yang dihuni oleh para lansia sekaligus untuk meningkatkan pemberdayaan dalam meningkatakan derajat kesehatan lansia sehingga terwujud lansia mandiri, sehat dan sejahtera. Beberapa kegiatan yang akan dilakukann unntuk mencapai tujuan PPM di LRSU Minaula Kendari, sebagai berikut:

1. Penyuluhan kesehatan mengenai Inkontinensia Urine

Kegiatan penyuluhan kesehatan ini merupakan strategi awal untuk mengedukasi lansia sehingga dapat meningkatkan pengetahuan dan pemahaman lansia mengenai Inkontinensia urine termasuk upaya penanganan dini dan pencegahannya, serta meluruskan persepsi lansia terkait metode pencegahan yang paling efektif dan efisien.

2. Melakukan pelatihan dan demonstrasi senam kegel

Pelatihan senam kegel dilaksanakan di aula Yayasan Al Aziz Kendari yang merupakan mitra dari LRSU Minaula Kendari dengan peserta yang melibatkan pengurus yayasan serta seluruh lansia. Kegiatan ini menggunakan media audio visual melalui pemutaran video tutorial tentang cara melakukan senam kegel, demonstrasi oleh pengurus yayasan dan seluruh lansia.

3. Mengadakan/ melatih kader kesehatan sebagai pelatih lansia berikutnya, memantau lansia dalam pelaksanaan kegiatan senam kegel secara rutin dan mengevaluasi frekuensi Inkontinensia urine dan kemampuan berkemih secara normal pada lansia

Kegiatan yang dilakukan dalam pengabdian pada masyarakat ini akan melibatkan seluruh elemen masyarakat secara bersama-sama, sinergi, multidisiplin, dan bermitra sehingga jumlah kasus inkontinensia urine tidak bertambah dan mengalami penurunan serta tidak terjadi efek maupun komplikasi akibat Inkontinensia Urine.

\section{HASIL DAN PEMBAHASAN}

Kegiatan Pengabdian Pada Masyarakat di laksanakan di Yayasan Al Aziz yang merupakan mitra dari Loka Rehabilitasi Sosial Lanjut Usia Minaula Kendari melalui kegiatan "Peningkatan Kemampuan Berkemih Melalui Senam Kegel Bagi Lansia di Loka Rehabilitasi Sosial Lanjut Usia Minaula Kendari", yang terdiri dari 3 (tiga) kegiatan utama, yaitu :

a. Penyuluhan kesehatan tentang Inkontinensia urine dan sosialisasi senam kegel sebagai solusi untuk mencegah dan menangani Inkontinensia urine.

b. Melakukan latihan senam kegel bersama lansia dan kader 
c. Melakukan evaluasi pelaksanaan senam kegel dan kejadian inkontinensia urine pada lansia.

\section{Penyuluhan kesehatan tentang Inkontinensia urine dan sosialisasi senam kegel sebagai solusi untuk mencegah dan menangani Inkontinensia urine}

Kegiatan pertama yang dilakukan dalam rangakaian kegiatan pengabdian pada masyarakat ini adalah Penyuluhan kesehatan tentang Inkontinensia urine dan sosialisasi senam kegel sebagai solusi untuk mencegah dan menangani Inkontinensia urine. Kegiatan ini dilaksanakan pada hari Minggu, 20 November 2019 pada pukul 08.00-12.00 WITA, bertempat di Aula Yayasan Al Aziz Kendari. Kegiatan ini dihadiri oleh Ketua dan pengurus Yayasan Al Aziz, tokoh masyarakat dan seluruh lansia binaan yayasan yang masih aktif dan produktif berjumlah 50 lansia.

Tujuan dari kegiatan penyuluhan kesehatan tentang Inkontinensia urine adalah untuk meningkatkan pengetahuan lansia mengenai Inkontinensia urine, menanamkan kesadaran untuk mencegah terjadinya inkontinensia urine serhingga dapat meningkatkan status kesehatan lansia.

Inkontinensia urine adalah keluhan keluarnya urin di luar kehendak sehingga menimbulkan masalah sosial dan/atau kesehatan. Oleh karena itu, kegiatan ini perlu dilakukan mengingat berbagai macam perubahan fungsi fisiologis pada beberapa organ yang terjadi pada lanjut usia, salah satunya adalah pada system perkemihan dimana terjadi penurunan tonus otot vagina dan otot pintu saluran kemih (uretra) yang disebabkan oleh penurunan hormone esterogen, sehingga otototot perkemihan menjadi lemah dan dapat menyebabkan terjadinya Inkontinensia Urine (Nugroho. W, 2008).

Melengkapi tujuan utama pencegahan Inkontinensia Urine, juga dilakukan sosialisasi tentang senam kegel sebagai salah satu upaya untuk mencegah dan menangani masalah Inkontinensia Urine (Stanley, M. 2007).

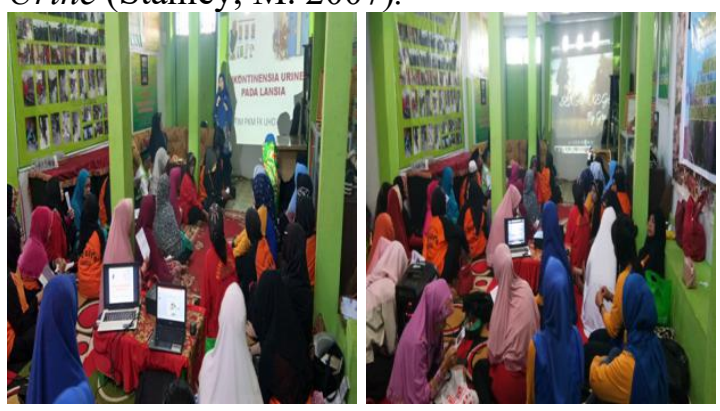

Gambar 1. Penyuluhan dan Sosialisasi Inkontinensia Urine dan senam kegel

Kegiatan ini diawali dengan sambutan dari Ketua Konsentrasi Ilmu Keperawatan Fakultas Kedokteran Universitas Halu Oleo, dilanjutkan dengan kata sambutan oleh Ketua Yayasan Al Aziz Kendari sekaligus membuka kegiatan penyuluhan dan sosialisasi. Sebelum penyampaian materi penyuluhan, peserta yang hadir diberikan leaflet tentang Inkontinensia Urine dan cara melakukan senam kegel (Gambar 4 dan Gambar 5). Selain leaflet juga digunakan media LCD untuk meningkatkan efektifitas pencapaian tujuan.

Materi yang disampaikan pada kegiatan penyuluhan kesehatan yang disampaikan oleh ketua Tim pengabdian adalah tentang Inkontinensia urine meliputi pengertian Inkontinensia urine, klasifikasi, penyebab, gejala, komplikasi, dan penanganan Inkontinensia urine. Selain penyuluhan, pada kegiatan ini dilakukan juga sosialisasi tentang senam kegel dan cara melakukan senam kegel.

Proses penyuluhan berjalan dengan lancar dan peserta yang hadir diberikan kesempatan untuk bertanya sehingga terjadi diskusi interaktif antara Tim pemateri dengan seluruh lansia yang hadir. Dengan dilakukannya kegiatan sosialisasi ini, maka diharapkan pengetahuan dan kesadaran lansia tentang Inkontinensia urine serta pencegahannya menjadi lebih baik, sehingga kejadian Inkontinensia urine dapat dicegah, frekuensi kejadiannya menurun sehingga dapat meningkatkan kualitas berkemih dan kualitas hidup lansia. 


\section{Pelatihan Senam Kegel}

Kegiatan pelatihan senam kegel merupakan hal penting untuk menyukseskan kegiatan pengabdian pada masyarakat ini dalam rangka meningkatkan kualitas dan kemampuan berkemih pada lansia. Kegiatan ini dilaksanakan bersamaan dengan kegiatan penyuluhan tentang Inkontinensia urine yaitu pada Hari Minggu Tanggal 20 Oktober 2019. Peserta kegiatan ini adalah seluruh lansia binaan Yayasan Al Aziz Kendari. Waktu ini dipilih karena bertepatan dengan kegiatan rutin "Day Care Lansia" yang diadakan setiap hari minggu sehingga lebih banyak lansia yang hadir dan mengikuti latihan senam kegel secara antusias. Kegiatan ini dilaksanakan secara formal bertempat di Aula Yayasan Al Aziz Kendari, tempat rutinitas kegiatan untuk para lansia.
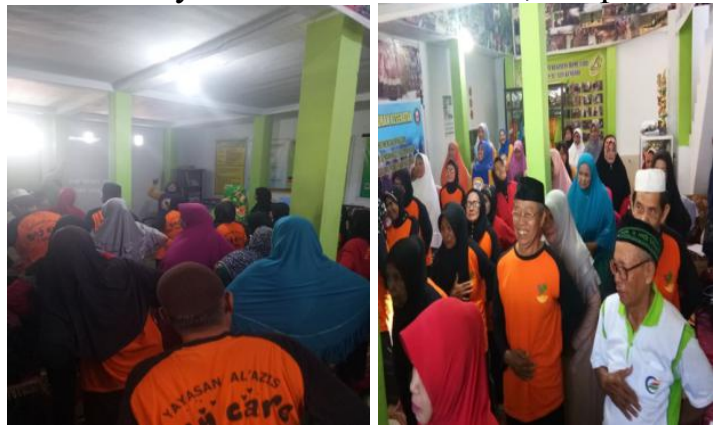

Gambar 2. Latihan Senam Kegel

Tindak lanjut dari pelatihan ini adalah memberikan lembar observasi pelaksanaan senam kegel kepada lansia untuk mengevaluasi pelaksanaan senam kegel dan mengevaluasi frekuensi Inkontinensia urine pada lansia.

\section{Evaluasi pelaksanaan senam kegel dan kejadian inkontinensia urine pada lansia}

Evaluasi pelaksanaan senam kegel dan frekuensi Inkontinensia urine pada lansia dilaksanakan selama dua minggu yaitu pada Hari Minggu Tanggal 27 Oktober 2019 dan Hari Minggu Tanggal 10 November 2019.

Kegiatan evaluasi dilakukan secara langsung oleh Tim Pengabdian kepada seluruh lansia dengan mengumpulkan lembar observasi dan wawancara langsung terkait pelaksanaan senam kegel seara rutin dirumah dan evaluasi keluhan inkontinensia.

Dari 50 lansia yang melakukan senam kegel secara rutin, memberikan efek positif dimana lansia mengalami peningkatan kemampuan berkemih dengan baik, dan menurunnya kejadian keluarnya urine secara spontan tanpa disadari (mengompol).

\section{KESIMPULAN}

Berdasarkan hasil kegiatan, Hal yang dapat disimpulkan adalah lansia dengan masalah Inkontinensia urine mengalami peningkatan kualitas dan kemampuan berkemih dengan baik setelah mengimplementasikan senam kegel secara rutin. Kegiatan penyuluhan kesehatan serta latihan senam kegel ini perlu senantiasa dilakukan guna memberikan solusi sebagai alternative agar dapat memberikan manfaat promotif dan preventiv kesehatan terutama pada lansia baik yang mengalami maupun yang belum mengalami masalah inkontinensia urine, sehingga hal ini dapat meningkatkan kualitas hidup para lansia.

\section{DAFTAR PUSTAKA}

Anggelita, 2012. Latihan Kegel Dengan Penurunan Gejala Inkontinensia Urin Pada Lansia. Jurnal Keperawatan Klinis. Vol.1 Nomor 1. Hal. 37-42

Darmojo, R. dan Martono, H. (2006). Buku Ajaran Geriatric Ilmu Kesehatan Usia Lanjut, Balai Penerbit Fakultas Kedokteran Universitas Indonesia FKUI, Jakarta.

Depkes, 2012. Riset Kesehatan Dasar Tahun 2012. Jakarta: Depkes RI.

Dunn MJ. 1990. The National Kidney and Urologyc Disease Advisory Board. J Am Soc Nephrol. Vol.1(1):7-8.

LRSU Minaula Kendari, 2018. Profil LRSU Minaula Kendari. Kendari 
Maas, M. L., Buckwalter, K. C., Hardy, M. D., Tripp-Reimer, T., Titler, M. G., \& Specht, J. P. (2011). Asuhan Keperawatan Geriatrik, Diagnosis NANDA, Kriteria Hasil NOC, Intervensi NIC. Jakarta: EGC.

Nugroho, W. 2008. Keperawatan Gerontik \& Geriatrik Edisi 3. Jakarta: EGC.

Pudjiastuti. 2003. Fisioterapi pada Lansia.Jakarta: EGC

Purnomo, 2012. "Perbedaan Keseimbangan Tubuh Lansia Berdasarkan Keikut sertaan Senam Lansia Di Panti Werda Pelkris Pengayoman Dan Elim Semarang”. Journal Balance of Body, Gymnastics elderly.Vol.6.No.1. Hal:2.

Rahardjo E. H., 2012. Panduan Tata Laksana Inkontinensia Urin pada Dewasa, Jakarta : PERKINA Stanley, M., \& Beare, P. G. 2006. Buku Ajar Keperawatan Gerontik Edisi 2. Jakarta: EGC.

Stanley, M. 2007. Buku Ajar Keperawatan Gerontik. Jakarta: EGC

Wandera S, Betty, James. 2015. Determinants od access to healthcare by older persons in uganda: a cross-sectional study. Int J for Equity in Health. 14(26):1-10 